\title{
Launch Facilities for Sale Worldwide
}

by our Washington Correspondent

ThE White House announced last week that the United States is prepared to launch scientific and applications satellites for any country willing to purchase the launch facilities. The only constraints on this broad offer are that the satellites must be for peaceful purposes and that the launching must be consistent with US obligations under international agreements and arrangements, particularly the Intelsat agreement.

The announcement signals the extension to other countries of the agreement reached last year between the United States and the European Space Conference (see Nature, 234, 266 ; 1971). According to $\mathrm{Dr}$ Robert $\mathrm{T}$. Webber, acting Director of the office of space affairs in the Department of State, "it reaffirms that agreement at the highest possible level". Apart from European countries, the chief beneficiaries of US willingness to launch foreign satellites are likely to be first Japan and later possibly India. And, because the offer also extends to international organizations, specialized agencies of the United Nations have a route into space if they ever want to get into the satellite business.

The effect of the agreement is, however, largely symbolic for NASA has already launched some 16 satellites for foreign countries, and there seemed every chance that it would continue to do so even without such a broad agreement. But for the European Space Conference, the announcement last year and its reaffirmation last week is important because it divorces the question of launcher availability from discussions about possible European participation in the post-Apollo programme.

Until last year's announcement, there was considerable controversy in the European scientific community about whether or not the United States would continue to launch European satellites if the European Space Conference decided that it wanted no part of the post-Apollo programme. But the European Space Conference is now putting together its reaction to NASA's invitation to join in the shuttle and related programmes with the knowledge that American launchers will be available to member countries whatever they decide on the shuttle offer.

As for Japan, the broad offer of US launch facilities is being welcomed for several reasons. Although the Japanese space agency is building Thor-Delta rockets under licence with the United States government, the launcher will not be powerful enough to place into orbit a series of meteorological satellites that the Japanese Space Developments Agency wants to launch in 1976. The satellites will be part of the Global Atmospheric Research Program (GARP), and negotiations were well under way between the Japanese and US governments for launch facilities well before last week's announcement. The announcement may, however, help oil the negotiations.

Both the Japanese and Indian governments are also thinking of setting up domestic communications satellite networks, and US launchers may be required to place them into orbit. The United States would probably have no objection to launching such satellites since they would be used solely for

\section{RAW MATERIALS}

\section{A Limit to Growth}

by our Washington Correspondent

AN ad hoc committee of the National Research Council has added its voice to the call for tighter government controls over the way raw materials are used in the United States. The committee, which met under the chairmanship of Dr Preston Cloud of the University of California, believes that unless a national materials policy is soon adopted in the United States, "one can foresee, within decades ... the erosion of the United States mining, smelting, refining, and mineral-based industries, growing economic colonialism, international frictions, a steadily deteriorating balance of trade, and a tarnished global image of the nation".

The reason for the committee's dire prediction is the familiar story of burgeoning per capita consumption of natural resources, stagnant domestic production of raw materials and rapidly increasing world population. The committee points out, for example, that the United States is already almost completely dependent on foreign sources for twenty-two of the seventyfour minerals (coal and oil apart) considered essential for a modern industrial society, and cites a report published by the Secretary of the Interior earlier this year which estimated that by the end of the century, domestic supplies of primary raw materials would be sufficient to meet only 46 per cent of the demand. Unfortunately, however, the report, on the committee's own domestic broadcasting and therefore would not come under the Intelsat agreement. As far as the Japanese system is concerned, the Thor-Delta rocket may be sufficiently powerful for putting the satellites into orbit, but it may not be ready in time. The Indian system, on the other hand, is unlikely to be ready until at least the late 1970s.

In short, the offer announced last week--referred to by President Nixon as "a global launch assurance policy" -is that the United States will provide launch facilities for other countries on a reimbursable basis. The launch could take place either from US sites or from foreign sites simply by purchase of a rocket. In theory, the offer also extends to China-Dr Webber said last week that such a prospect "may seem remote at the moment, but in seven or eight years time ...?'

admission, is more concerned with pointing out the problems than with providing the solutions.

According to $\mathrm{Dr}$ Cloud, however, there was little support in the committee for the view that market forces alone will solve the foreseeable problems related to better resource use, and the time is ripe for government action. A materials policy should be developed which should aim to reexamine the policies of material growth, base industrial production as far as possible on widespread and abundant basic commodities, more efficiently develop resources without "unacceptable" environmental costs and limit population growth.

How can the government help address these problems? One of the first requirements is a firm data base on which to build policies, and the committee therefore argues for more complete mineralogical mapping of the United States, more research on ecosystem dynamics and the development of more information on the trends in resource use. Having established the data base, the committee suggests that the government should provide "straightforward, equitable and flexible" incentives to help promote more efficient use of resources and to help base industrial production on the more abundant raw materials. Such government actions could include direct intervention in the market, either as buyer or seller, and even nationalization of limited stocks of critical materials. Specifically, the committee recommends that a permanent advisory committee on minerals policy should be formed. 